\title{
WYBRANE REALIZACJE BUDYNKÓW Z KONSTRUKCJĄ NOŚNĄ WYKONANĄ Z ZASTOSOWANIEM STALI FRS ODPORNYCH NA TEMPERATURĘ POŻAROWA
}

\begin{abstract}
W pracy pokazano przykłady zastosowania konstrukcyjnych stali FRS, odpornych na temperaturę pożarową, w ustrojach nośnych byłych lub nadal użytkowanych obiektów budowlanych. Stale tego typu ze względu na swoje właściwości nie muszą być specjalnie chronione na wypadek ich potencjalnej ekspozycji ogniowej w pożarze rozwiniętym. Stanowią zatem interesującą alternatywę w stosunku do tradycyjnych stali konstrukcyjnych, wymagających dodatkowej, kosztownej, izolacji przeciwogniowej. Praktyczne wykorzystanie prezentowanych stali ogranicza się jak dotąd do Japonii, co wynika ze specyfiki obowiązującego w tym kraju prawa budowlanego, niemniej jednak pewne kroki w tym kierunku podjęto w ostatnim czasie również w krajach Unii Europejskiej. Głównymi obszarami stosowania stali FRS są do tej pory: budynki wysokie, w tym zewnętrzne nośne części ich elewacji, obiekty sportowe, otwarte garaże wielokondygnacyjne, a także sale widowiskowe $\mathrm{z}$ atriami.
\end{abstract}

Słowa kluczowe: stale FRS, pożar, temperatura, odporność ogniowa, spawalność, wytrzymałość.

\section{Wprowadzenie}

Jedną z podstawowych wad klasycznych stali konstrukcyjnych, powszechnie stosowanych w ustrojach nośnych różnego typu obiektów budowlanych, jest ich stosunkowo mała odporność na temperaturę pożarową. Z tego względu wymaga się aby w praktycznych zastosowaniach elementy konstrukcyjne wykonane $\mathrm{z}$ tych stali były chronione przed potencjalną bezpośrednią ekspozycją ogniową. Zabezpiecza się je zatem na wypadek zaistnienia pożaru, na ogół przez

\footnotetext{
${ }^{1}$ Autor do korespondencji: Mariusz Maślak, Politechnika Krakowska, ul. Warszawska 24, 31-155 Kraków, tel.: +48126415673, e-mail: mmaslak@pk.edu.pl

2 Ryszard Skiba, Politechnika Krakowska, ul. Warszawska 24, 31-155 Kraków, tel. +48126282306, e-mail: rskiba@pk.edu.pl
} 
naniesienie specjalnych pęczniejących powłok malarskich, natrysk warstwy tynku ogniochronnego na zamocowaną na elemencie stalowym siatkę drucianą lub cięto - ciągnioną albo obłożenie okładzinami wykonanymi $\mathrm{z}$ materiałów izolacyjnych. Parametry takiej izolacji dobiera się tak aby realna odporność chronionego przez nią elementu stalowego była co najmniej równa odporności wymaganej przez prawo (lub wyższa od niej), przy założeniu, że miarodajnym przebiegiem pożaru będzie przebieg specyfikowany dla laboratoryjnego badania ogniowego, nie zaś dla pożaru faktycznie prognozowanego w rozpatrywanej strefie pożarowej. Niezależnie jednak od wyboru zastosowanej technologii prac związanych z wykonaniem odpowiedniej ochrony przed ogniem trzeba liczyć się ze znacznymi kosztami oraz dużą materiałochłonnością i czasochłonnością robót. Koszty te zresztą w ostatnim czasie znacząco wzrosły, co jest wynikiem zaostrzenia wymogów bezpieczeństwa. $Z$ tego względu od lat poszukuje się alternatywnych podejść pozwalających na uzyskanie porównywalnej odporności ogniowej elementu stalowego bez stosowania klasycznych izolacji przeciwogniowych. Pewne nadzieje wiąże się na tym polu z wypełnianiem przestrzeni pomiędzy półkami nośnego kształtownika stalowego betonem zbrojonym o dużej pojemności cieplnej. Półki te, co prawda, w razie pożaru podlegają bezpośredniej ekspozycji ogniowej, nie są bowiem w żaden sposób izolowane, jednak ich temperatura narasta znacznie wolniej bowiem energia cieplna dostarczana do układu jest $\mathrm{w}$ dominującej części akumulowana przez wprowadzony beton. Rozwiązanie takie, jakkolwiek powszechnie stosowane, ma jednak dość ograniczone zastosowanie z powodu znaczącej różnicy w odkształcalności rozgrzanej stali i współpracującego z nią betonu. Celem niniejszej pracy jest prezentacja możliwości wykorzystania na tym polu rozwiązania alternatywnego, opartego na koncepcji projektowania elementów nośnych potencjalnie eksponowanych ogniowo ze stali o podwyższonej odporności na temperaturę pożarową, czyli tak zwanych stali FRS.

\section{Idea projektowania stali FRS}

Do grupy stali FRS (fire resistant steels) zalicza się stale konstrukcyjne, które w pożarze rozwiniętym odpowiednio długo zachowują wymagany poziom granicy plastyczności $f_{y, \Theta}$, redukowanej w temperaturze $\Theta$, tak że zachodzi $f_{y, \Theta}=k_{y, \Theta} f_{y}$, gdzie $f_{y}$ jest wartością nominalną tej granicy odniesioną do temperatury pokojowej. Drugą niezbędną cechą jest gwarancja aby spawalność tych stali identyfikowana $\mathrm{w}$ odniesieniu do warunków ich ekspozycji na temperaturę pożarową była wystarczająco dobra, to znaczy co najmniej porównywalna $\mathrm{z}$ tą która cechowała je przed rozgorzeniem pożaru. Zgodnie $\mathrm{z}$ definicją opracowaną przez Japan Institute of Metals [1] stopień redukcji granicy plastyczności tego typu stali nie może w temperaturze $600{ }^{\circ} \mathrm{C}$ być większy niż dwie trzecie licząc w stosunku do granicy plastyczności tej samej stali specyfi- 
kowanej dla temperatury pokojowej, co oznacza nałożenie formalnego ograniczenia $k_{y, 600}=\left(f_{y, 600} / f_{y}\right) \geq 0,667$. Trzeba podkreślić, że jest ono znacznie bardziej konserwatywne niż analogiczne ograniczenie zawarte w przepisach amerykańskich [2], które można sprowadzić do postaci $k_{y, 600} \geq 0,500$. Zauważmy przy tym, że zgodnie danymi zawartymi w normie PN-EN 1993-1-2 [3] konwencjonalne niestopowe stale konstrukcyjne charakteryzuje redukcja na poziomie $k_{y, 600}=0,470$. Uzyskanie stali odpornych na działanie wysokiej temperatury samo w sobie nie jest specjalnie trudne a technologia ich wytwarzania już stosunkowo dobrze opanowana. Wystarczy przywołać tu klasyczne stale cechujące się żarowytrzymałością (cechy tej nie należy mylić z żaroodpornością [4]). Nie są to jednak stale konstrukcyjne, trudno zatem stosować je w ustrojach nośnych obiektów budowlanych. Powszechnie wiadomo, że jedyną drogą prowadzącą do wytworzenia stali o pożądanej odporności na działanie temperatury pożarowej i spełniającej równocześnie konwencjonalne wymagania konstrukcyjne jest odpowiednia modyfikacja typowych stali stosowanych w tym samym celu w temperaturze pokojowej. Na ogół dąży się do tego aby poprzez odpowiednią obróbkę stali w miejsce klasycznej struktury ferrytyczno - perlitycznej uzyskać strukturę mieszaną bainityczno - ferrytyczną [5]. Poza tym poprzez odpowiedni dobór domieszek, zwłaszcza molibdenu i wanadu, koryguje się skład chemiczny modyfikowanej stali co prowadzi do blokowania rozwoju i przemieszczania się dyslokacji w jej sieci krystalicznej a w efekcie do zintensyfikowania mechanizmów strukturalnych skutkujących jej umocnieniem. Dokładniejsze omówienie tych zagadnień wymaga osobnego, obszernego opracowania. Poświęcono im między innymi pracę [6] a także szczegółowy referat [7] przygotowany przez autorów niniejszego artykułu.

Pierwsze badania poświęcone wypracowaniu miarodajnego algorytmu projektowania struktury i składu chemicznego stali konstrukcyjnych odpornych na temperaturę pożarową, zwanych dziś stalami FRS, były prowadzone we francuskiej firmie Creusot-Loire już we wczesnych latach siedemdziesiątych ubiegłego wieku. Nie dały one jednak satysfakcjonujących wyników ze względu na brak zrozumienia efektów termomechanicznych identyfikowanych podczas eksperymentów. Badania te były następnie kontynuowane przez australijską spółkę BHP (Broken Hill Proprietary) ale koncentrowały się raczej wokół stali czysto ferrytycznych. Obiecujące i praktycznie ważne rezultaty uzyskano na tym polu dopiero $w$ latach dziewięćdziesiątych dwudziestego wieku. Był to już czas kiedy powyższe badania zostały zdominowane przez duże przedsiębiorstwa japońskie, w szczególności przez Nippon Steel ale później także przez Kawasaki Steel i Sumitomo Metals. Procedury projektowania stali FRS kolejno proponowane przez Japończyków były i nadal są weryfikowane dzięki eksperymentom prowadzonym w wielu ośrodkach naukowych, w szczególności w Queen's University w Belfaście w Irlandii Północnej. Wydaje się, że obecny stan wiedzy pozwala już na tyle precyzyjnie dobrać skład chemiczny 
oraz parametry procesu wytwarzania aby w efekcie ich zastosowania otrzymać stal konstrukcyjną o pożądanej odporności ogniowej. Nadal jednak będzie ona na tyle droga, że jej niewątpliwe zalety nie zrekompensują kosztów jej wytworzenia, zwłaszcza jeśli odnieść te koszty do kosztów tradycyjnego zabezpieczenia niezbędnego do wykonania $\mathrm{w}$ przypadku zastosowania konwencjonalnych stali konstrukcyjnych. Trzeba przy tym podkreślić fakt, że uzyskane rezultaty naukowe poskutkowały wprowadzeniem do obowiązującego w Japonii prawa budowlanego przepisu pozwalającego na wykorzystanie stali FRS bez towarzyszącego jej zabezpieczenia przeciwpożarowego do ustrojów nośnych obiektów budowlanych. Przepis ten jest jednak warunkowany otrzymaniem indywidualnie dla każdego projektowanego obiektu tak zwanego odstępstwa zatwierdzonego przez tamtejszego Ministra Budownictwa [1]. Pozwolenie to wystawiono jak dotąd jedynie dla budynków z małą ilością materiałów palnych (to znaczy o małej gęstości obciążenia ogniowego wydzielonych w nich stref pożarowych), jeżeli można było zagwarantować, że temperatura stalowych elementów nośnych wykonanych ze stali FRS nie przekroczy podczas pożaru wartości $600^{\circ} \mathrm{C}$.

\section{Hala sportowa „Gymnasium” w Tokoname}

Pierwszy z prezentowanych przykładów dotyczy ustroju nośnego hali sportowej „Gymnasium” wybudowanej w Tokoname w prefekturze Aichi w środkowej Japonii (stolicą tej prefektury jest miasto Nagoja). Budynek jest obiektem czterokondygnacyjnym $\mathrm{z}$ dachem o wymiarach $100,7 \times 50,4 \mathrm{~m}$ (rys. 1a). Przestrzenna kratowa konstrukcja dachu opiera się na czterech płaskich kratownicach o wysokości 13,38 m. Jak łatwo zauważyć na rys. 1c kratownice te, rozstawione obwodowo, wyprowadzono na odległość $2,10 \mathrm{~m}$ przed obrys elewacji obiektu. Tego typu zabieg pozwolił na wykorzystanie do ich wytworzenia stali FRS (rys. 1b). Z rozważanego scenariusza pożaru, który rozgorzał wewnątrz budynku, wynikało bowiem, że temperatura płomienia ogarniającego taki wystawiony na zewnątrz kratowy dźwigar nośny będzie zbyt niska aby rozgrzać ten dźwigar do temperatury wyższej niż $600{ }^{\circ} \mathrm{C}$. Jest to konsekwencją zmiany dynamiki pożaru po jego wydostaniu się na zewnątrz rozpatrywanego pomieszczenia (ściślej - na zewnątrz wydzielonej w budynku strefy pożarowej). Tempo nagrzewania się konstrukcji stalowej, w żaden sposób nie chronionej przed bezpośrednią ekspozycją ogniową, jest w takim przypadku wyraźnie wolniejsze. Rozwój pożaru w bliskim otoczeniu wiązara odpowiada bowiem modelowi tak zwanego pożaru zewnętrznego (external fire), nie zaś pożarowi parametrycznemu (parametric fire) o znacząco większej intensywności, typowemu dla stref pożarowych o ograniczonych możliwościach ich wentylacji [8]. Na rys. 1c pokazano, że modelowany płomień ogarniający wiązar wykonany ze stali FRS, o wysokości $8,30 \mathrm{~m}$ i głębokości oddziaływania $5,53 \mathrm{~m}$, spowodował rozgrzanie prętów kratownicy jedynie do poziomu $531,4{ }^{\circ} \mathrm{C}$. Dodatkowa weryfikacja 
przemieszczeń rozpatrywanych wiązarów, przeprowadzona dla sytuacji pożarowej, wykazała że w tak oszacowanej temperaturze nie będą one na tyle duże aby generować zagrożenie wystąpienia jakiejkolwiek formy niestateczności (lokalnej lub globalnej).

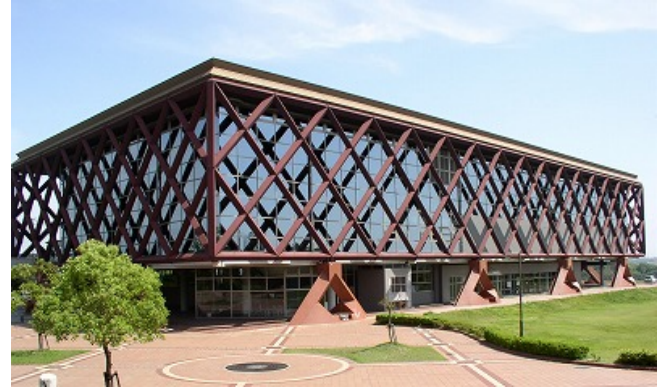

a)

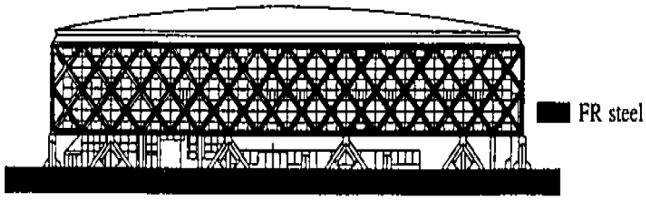

b)

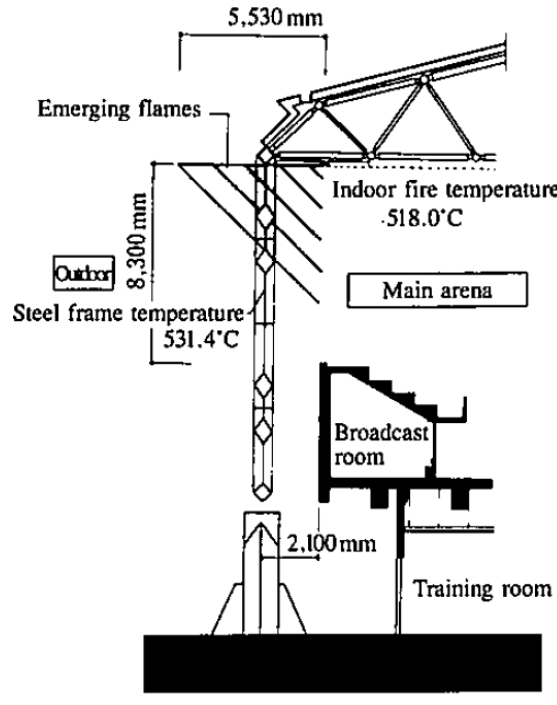

c)

Rys. 1. Hala sportowa „Gymnasium” w Tokoname: a) widok ogólny [10], b) kratowe dźwigary nośne wykonane ze stali FRS (na podstawie [1]), c) przekrój poprzeczny z naniesionymi wynikami symulacji rozwoju pożaru (na podstawie [1]).

Fig. 1. The sports hall "Gymnasium" in Tokoname: a) a general view [10], b) the load-bearing lattice girders made of the FRS-type structural steel (according to [1]), c) a hall crosssection on which the results of a fire simulation are shown in detail (according to [1]).

\section{Budynek urzędu pocztowego „Tobata Tobihata” w Kitaky- ushu}

Analogiczna idea wykorzystania stali FRS w wysuniętym przed obrys elewacji stalowym ramowym ustroju nośnym przyświecała projektantom budynku urzędu pocztowego w Kitakyushu w prefekturze Fukuoka (rys. 2). Obiekt ten nosi lokalną nazwę „Tobata Tobihata”. W tym przypadku z analizy najbardziej niekorzystnego dla konstrukcji scenariusza modelowanego pożaru wynikało, że płomienie wydostające się przez rozbite okna na zewnątrz strefy pożarowej i obejmujące zlokalizowane poza ścianami zewnętrznymi nie chronione przed ogniem stalowe słupy, a także rygle ramy nośnej w bezpośrednim sąsiedztwie węzłów, rozgrzeją je podczas potencjalnego pożaru jedynie do wartości $543{ }^{\circ} \mathrm{C}$. Oznacza to, że graniczny dopuszczalny poziom $600{ }^{\circ} \mathrm{C}$ w elementach tej konstrukcji nie zostanie osiągnięty. 


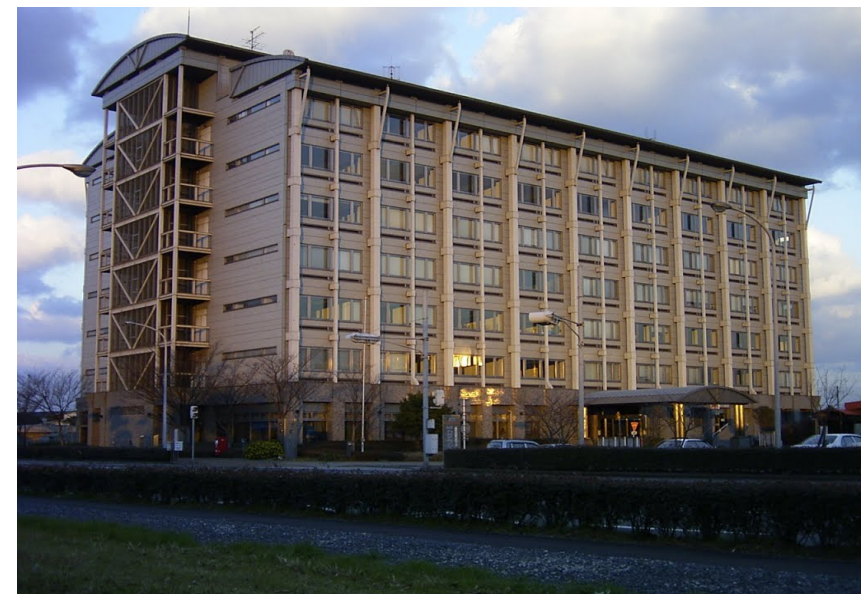

Rys. 2. Budynek urzędu pocztowego „Tobata Tobihata” w Kitakyushu z ramową konstrukcją nośną wykonaną ze stali FRS i wysuniętą poza obrys elewacji obiektu (opis budynku zamieszczono w [9], zdjęcie ze strony internetowej [11]).

Fig. 2. The post office building "Tobata Tobihata" in Kitakyushu with the frame load-bearing structure made of the FRS-type structural steel and localized beyond the outline of the facade of the building (the building description is given in [9], the presented photo is taken from the web-page [11]).

\section{Budynek bylego hotelu „Sofitel” w Tokio}

Kolejnym obiektem, niejako „sztandarowym” dla konstrukcji z ustrojem nośnym wykonanym ze stali FRS, był budynek hotelu „Sofitel” zlokalizowany w Tokio, na obrzeżach parku Ueno. Hotel ten pierwotnie nosił nazwę „Hokke Club Ikenohata Hotel" i pod tą nazwą opisywany jest w literaturze [1]. Prezentowany budynek rozebrano w 2006 roku po jedynie 12-letnim okresie użytkowania. Przyczyną takiej decyzji była nieopłacalność jego utrzymywania w charakterze jedynego w swoim rodzaju hotelu należącego do uznanej sieci o światowym zasięgu. Architektura tego obiektu była bowiem bardzo nietypowa (rys. 3a). W zamierzeniu projektanta miała ona odtwarzać „drzewo życia” - symbol powszechnie stosowany w japońskich świątyniach shintoistycznych. Budynek był stosunkowo wysoki $(110 \mathrm{~m})$, niemniej jego bryła została rozbita na pięć jednakowych czterokondygnacyjnych segmentów. Szerokość tych segmentów wynosiła jedynie $8 \mathrm{~m}$, co dawało niepowtarzalny ale i bardzo nieekonomiczny w użytkowaniu rozkład pomieszczeń na poszczególnych kondygnacjach (rys. 3c). Ze względu na bardzo małą szerokość obiektu ramową konstrukcję nośną wyprowadzono na zewnątrz obrysu elewacji (rys. 3b), co umożliwiło wykonanie jej ze stali FRS. Konstrukcja wsporcza niejako zagłębiała się wewnątrz budynku w jego dolnych kondygnacjach, gdzie zlokalizowano atrium, w którym znajdowały się liczne kawiarnie (rys. 3d). Z obliczeń przeprowadzonych dla sytuacji pożarowej wynikało, że elementy konstrukcji nośnej wykonane ze stali FRS rozgrzeją się w potencjalnym 
pożarze jedynie do temperatury $430{ }^{\circ} \mathrm{C}$, a więc nie osiągną granicznej wartości $600{ }^{\circ} \mathrm{C}$. Za miarodajny do analizy przyjęto pożar, który rozgorzał w opisanym powyżej atrium, a modelowany płomień o rozmiarach $4,0 \mathrm{~m} \times 6,8 \mathrm{~m}$ ogarnął słup konstrukcji nośnej (rys. 4).

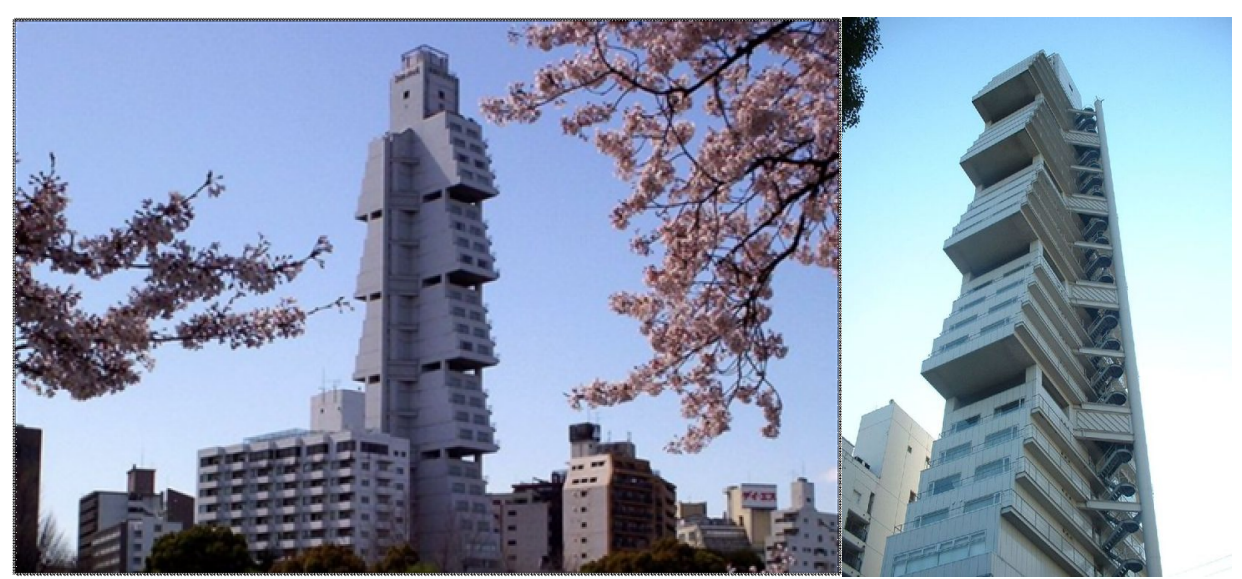

a)

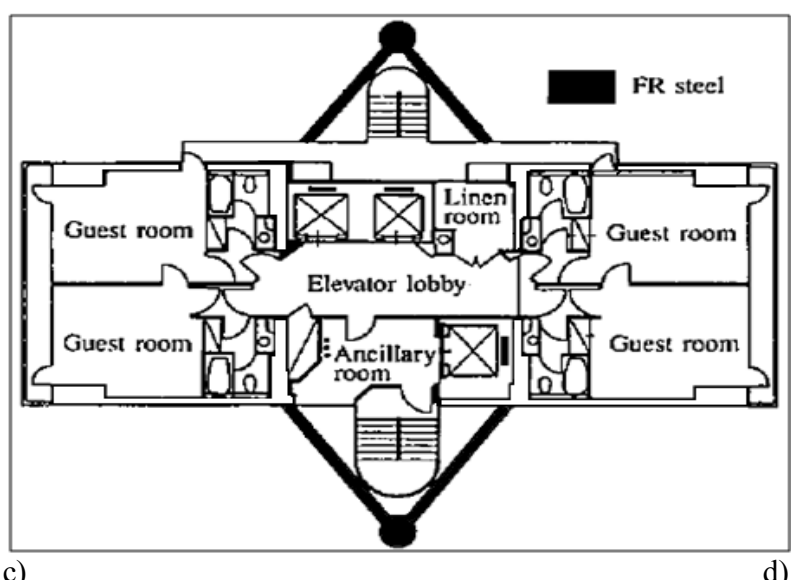

b)

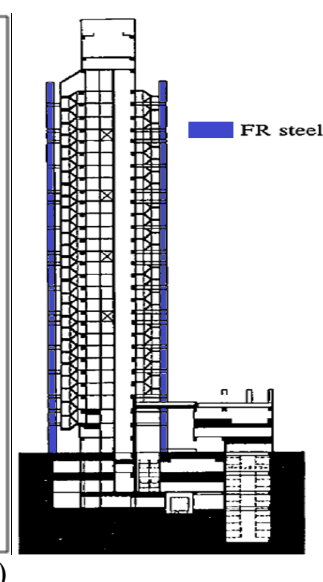

Rys. 3. Budynek byłego hotelu „Sofitel” w Tokio: a) widok ogólny [12], b) widok fragmentu konstrukcji nośnej wykonanej ze stali FRS [13], c) rzut poziomy typowej kondygnacji (na podstawie [1]), d) przekrój pionowy przez budynek z atrium zlokalizowanych w jego dolnych kondygnacjach (na podstawie [1]).

Fig. 3. The building of the former „Sofitel” hotel in Tokyo: a) a general view [12], b) a partial view of the building load-bearing structure made of the FRS-type structural steel [13], c) a horizontal projection of a typical hotel story (according to [1]), d) a vertical section through the building with an atrium located in the lower floors (according to [1]). 


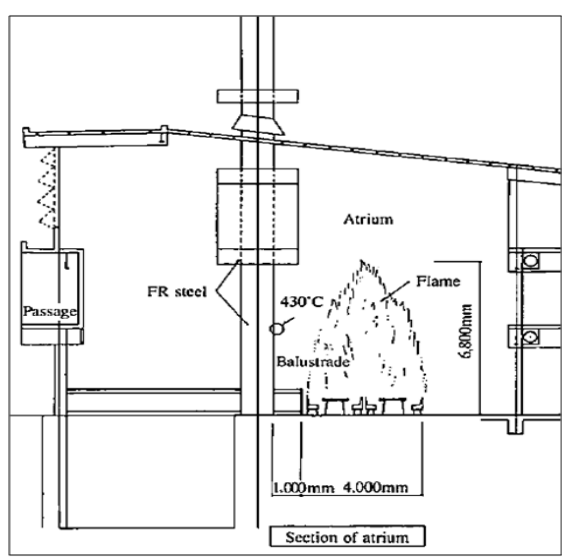

Rys. 4. Pożar w atrium jako reprezentatywny scenariusz pożarowy dla byłego budynku hotelu „Sofitel” w Tokio (na podstawie [1])

Fig. 4. The fire in the atrium as a fire scenario representative for the former "Sofitel" hotel building in Tokyo (according to [1]).

\section{Wielokondygnacyjny parking ponad budynkiem supermar- ketu ,Junnu Aurora Mall” w Chiba}

Następny prezentowany budynek z konstrukcją nośną wykonaną ze stali FRS to wielokondygnacyjny otwarty parking samochodowy wybudowany ponad supermarketem „Junnu Aurora Mall” w Chiba. W literaturze obiekt ten opisywany jest pod starą nazwą „Sen City Park Plaza Building” [1], związaną z dawnym właścicielem - siecią handlową „Sogo” (rys. 5a). Galeria handlowa ze sklepami zajmuje tam dolne poziomy, do czwartego piętra włącznie. Wyższe poziomy użytkowane są $\mathrm{w}$ charakterze parkingu. Dostęp do niego umożliwia zewnętrzna rampa zlokalizowana we wschodniej części budynku. Kolejne rampy, pozwalające na poruszanie się samochodami pomiędzy poszczególnymi poziomami parkingu, rozmieszczono wewnątrz (rys. 5b). Cały obiekt zaprojektowano na bazie sześciokąta o boku o długości $39,5 \mathrm{~m}$. Konstrukcję nośną budynku stanowią stalowe ramy poprzeczne prostopadłe do zewnętrznej elewacji i stężone w kierunku podłużnym (po obwodzie sześciokąta) kratownicami typu „K”. Miarodajnym scenariuszem pożarowym analizowanym przez projektantów był tu pożar pojedynczego samochodu ustawionego w bezpośrednim sąsiedztwie stalowego słupa newralgicznego ze względu na stateczność całego ustroju nośnego. Specyfiką pożarów, które mają miejsce w otwartych, wielokondygnacyjnych parkingach samochodowych jest to, że nie osiągają punktu rozgorzenia, ze względu na nieograniczony dostęp powietrza z zewnątrz do strefy pożarowej. Oznacza to w praktyce, że mają one zawsze charakter lokalny, co skutkuje tym, że temperatura elementów nośnych narażonych na bezpośrednią (bez dodatkowej izolacji) ekspozycję ogniową w potencjalnym pożarze narasta stosunkowo 
powoli. W opisywanym przypadku wykazano, że nie osiągnie ona granicznej wartości $600{ }^{\circ} \mathrm{C} . \mathrm{Z}$ tego względu rygle i słupy składające się na ustrój nośny parkingu wykonano ze stali FRS. Analogiczne rozwiązania parkingu zastosowano również w innym supermarkecie sieci „Sogo”, wybudowanym w Jokohamie (rys. 6a i $6 \mathrm{~b}$ ). Jedyną różnicą było to, że parkingi umieszczono tam na dolnych kondygnacjach budynku.

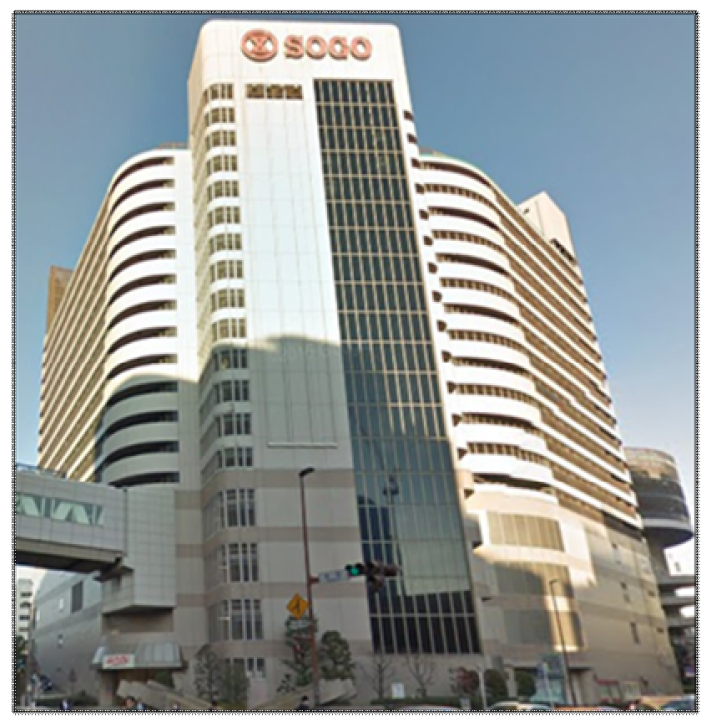

a)
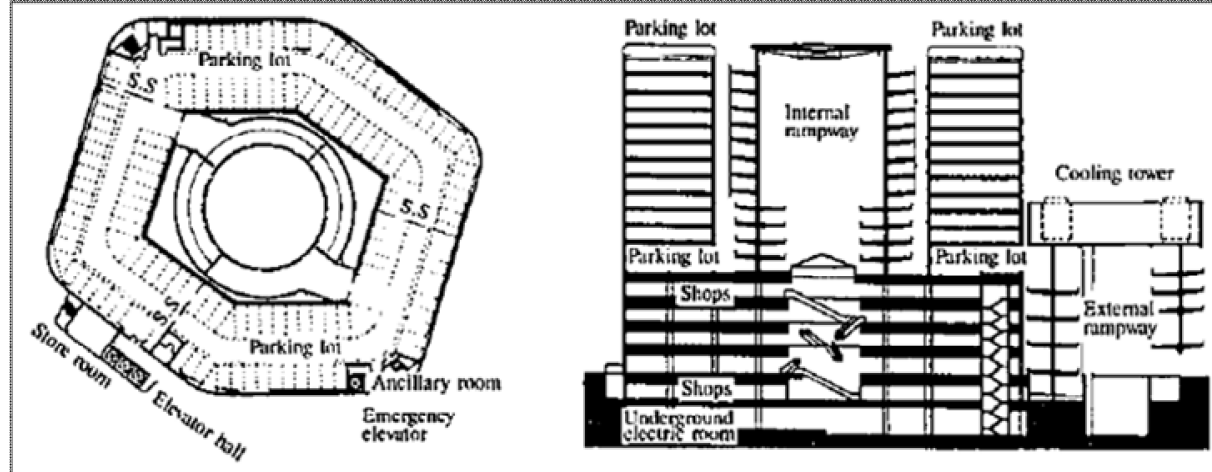

b)

Rys. 5. Budynek galerii handlowej sieci „Sogo” (obecnie „Junnu Aurora Mall”) w Chiba z wielokondygnacyjnym parkingiem samochodowym na górnych kondygnacjach: a) widok ogólny [14], b) rzut poziomy (na podstawie [1]).

Fig. 5. The building of the „Sogo" shopping mall (now "Junnu Aurora Mall”) in Chiba with a multi-story open car park on the upper floors: a) a general view[14], b) a horizontal projection (according to [1]). 


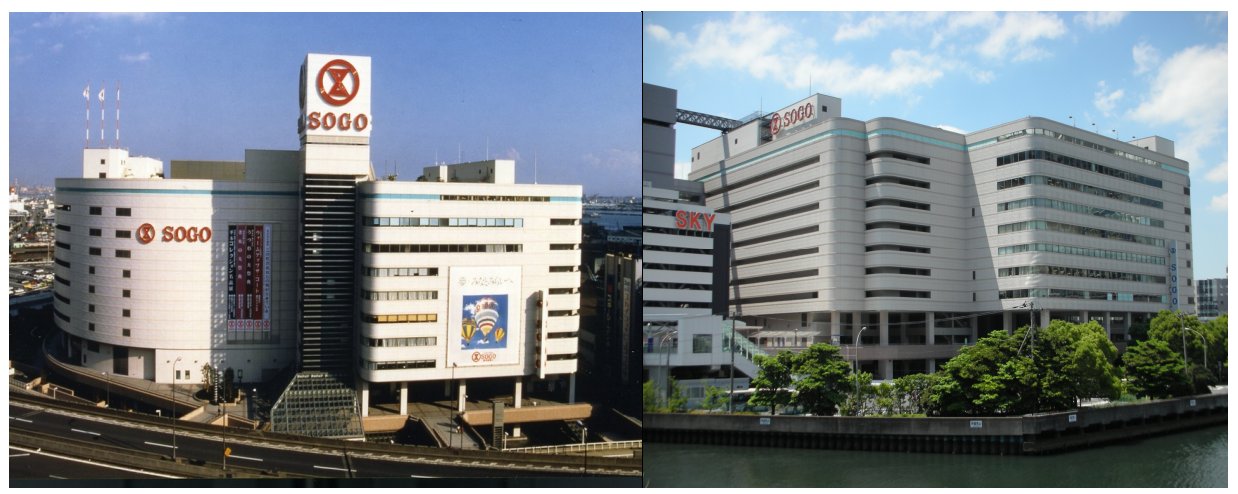

a)

b)

Rys. 6. Budynek galerii handlowej sieci „Sogo” w Jokohama z parkingiem na dolnych kondygnacjach: a) widok ogólny, b) widok od strony jeziora.

Fig. 6. The building of the "Sogo" shopping mall in Yokohama with an open car park on the lower floors: a) a general view, b) a view from the lake.

\section{Budynek centrum handlowego ,MEGA Don Quijote” w Mi- sato}

Ostatnim z budynków omawianych w niniejszym artykule jest galeria handlowa sieci „MEGA Don Quijote” wybudowana w mieście Misato w prefekturze Saitama. Pierwotnie było to centrum handlowe „La Park” należące do sieci „Nagasakiya” i pod tą nazwą zostało opisane w literaturze [1]. Na rys. 7a pokazano obecny wygląd elewacji budynku natomiast na rys. 7b jego przekrój poprzeczny. Charakterystyczne dla tego budynku jest centralne atrium ukształtowane $\mathrm{w}$ jednej z osi obiektu. Nad tym atrium zaprojektowano przeszklony dach rozpięty na powierzchni ćwierćcylindra (rys. 7b). Konstrukcję wsporczą tej części dachu wykonano ze stali FRS. Po obu stronach atrium zaprojektowano trzy kondygnacje użytkowe. $Z$ jednej strony na wszystkich tych kondygnacjach mieściły się sklepy, z drugiej natomiast (lewej na rys. 7b) sklepy zlokalizowano jedynie na dwóch dolnych kondygnacjach, na trzeciej zaś, a także na jej dachu, zaprojektowano parking samochodowy. Parking ten był oddzielony od atrium ścianą stanowiącą efektywne oddzielenie przeciwpożarowe (fire wall). Do szczegółowej analizy wytypowano w tym przypadku pożar, który rozgorzał na drugiej kondygnacji sklepowej, bezpośrednio pod kondygnacją z parkingiem. Taki modelowany pożar bez przeszkód przedostał się do atrium ale $\mathrm{z}$ uwagi na jego dużą kubaturę nie mógł rozprzestrzenić się równomiernie i zająć całej potencjalnie dostępnej tam objętości. Pozostał zatem pożarem o charakterze lokalnym, z płomieniem wydostającym się ze strefy rozgorzenia pożaru do wewnątrz atrium, o wymiarach i temperaturze pokazanych na rys. $7 \mathrm{~b}$. Po uwzględnieniu obciążenia ogniowego zgromadzonego w rozpatrywanej strefie pożarowej okazało się, że płomień ten nie był na tyle intensywny, a energia 
rozpraszana w pożarze na tyle duża, aby elementy nośne konstrukcji dachu podlegały bezpośredniej ekspozycji ogniowej. W przyjętym modelu znajdowały się one jednak długotrwale w otoczeniu gorących gazów spalinowych, co spowodowało ich nagrzanie. Maksymalną temperaturę tych elementów wyliczono na $316{ }^{\circ} \mathrm{C}$. Nie osiągała ona zatem granicznej wartości $600{ }^{\circ} \mathrm{C}$ formalnie dopuszczanej w przepisach japońskich dla stali FRS.

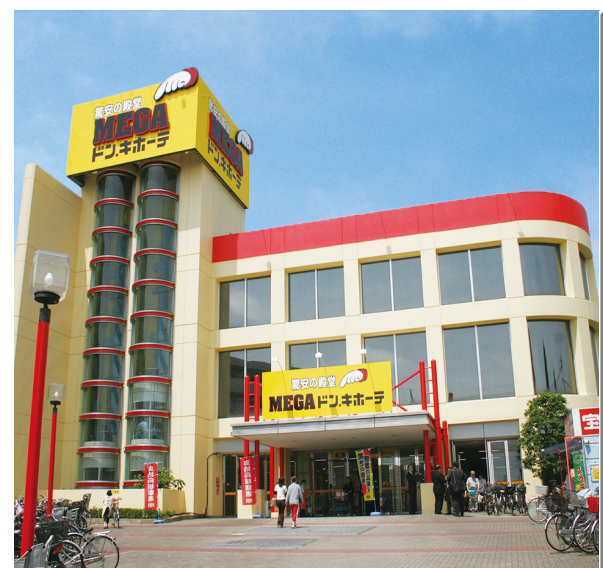

a)

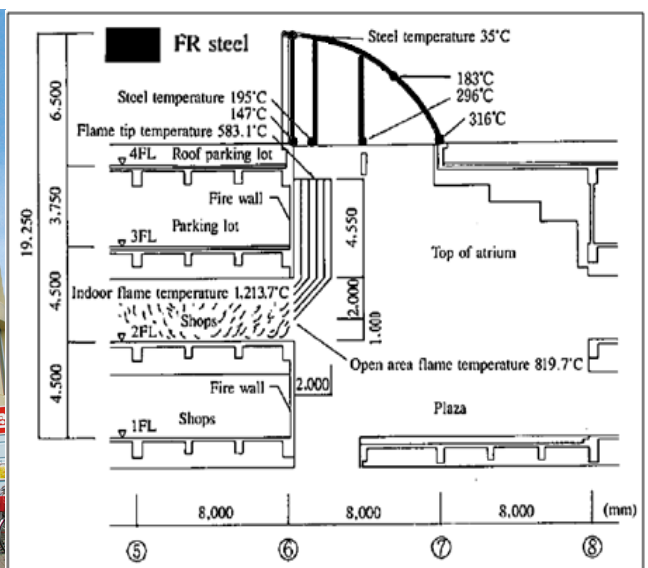

b)

Rys. 7. Budynek galerii handlowej sieci „MEGA Don Quijote” w Misato: a) widok ogólny [17], b) przekrój poprzeczny z atrium pokazanym po prawej stronie rysunku (na podstawie [1]).

Fig. 7. The building of the „MEGA Don Quijote” shopping mall in Misato: a) a general view [17], b) the building cross-section with an atrium shown on the right side of this figure (according to [1]).

\section{Uwagi końcowe}

Przykłady zaprezentowane w niniejszej pracy pokazują, że stale FRS mogą być efektywnie stosowane na konstrukcje nośne różnego typu obiektów budowlanych. Wystarczy tylko odpowiednio zaprojektować ramy wysuwając je przed obrys elewacji albo po prostu wykazać, że przy nagromadzonym w miarodajnej strefie pożarowej obciążeniu ogniowym potencjalny pożar nie będzie na tyle intensywny aby spowodował rozgrzanie elementów do temperatury wyższej niż $600{ }^{\circ} \mathrm{C}$. Wszystkie omawiane budynki zrealizowano w Japonii. Było to naturalną konsekwencją zdominowania rynku badań naukowych nad tego typu stalami przez firmy pochodzące z tego kraju. Sprzyjały temu i stymulowały prace badawcze odpowiednie przepisy lokalnego prawa budowlanego. Trzeba jednak odnotować, że po krótkotrwałej euforii obserwowanej na tym polu na przełomie wieków realizacje nowych budynków z elementami ustroju nośnego wykonanymi ze stali FRS nie są w ostatnim czasie raportowane w literaturze naukowej, 
także w Japonii. Jest to niewątpliwy skutek ogólnoświatowego kryzysu ekonomicznego, trudno jednak nie dostrzegać faktu, że wysokospecjalistyczna produkcja specjalnie projektowanych stali FRS jest nadal bardzo droga i mało konkurencyjna $\mathrm{w}$ stosunku do zastosowania tradycyjnych stali wraz z towarzyszącym im odpowiednim zabezpieczeniom na wypadek potencjalnej ekspozycji ogniowej. Zauważa się przy tym pewną intensyfikację prac badawczych nakierowanych raczej na lepsze zrozumienie termicznie generowanych zmian w sieci krystalicznej tego typu stali, a nawet na udoskonalenie procesu hutniczego prowadzącego do ich wytworzenia. Potrzebę poprawy odporności ogniowej stosowanych w budownictwie stali konstrukcyjnych coraz wyraźniej dostrzega się również w krajach Unii Europejskiej. Tutaj jednak wydaje się dominować nieco inne podejście związane z poszukiwaniem wydajniejszych i efektywniejszych powłok i okładzin izolacyjnych. Przykładem takiego postępowania niech będzie międzynarodowy program badawczy „Making steel more fire-resistant” (tak zwany program STEELPROST) rozwijany przez 7 krajów unijnych pod przewodnictwem Belgii w latach 2010-2012.

\section{Literatura}

[1] Fushimi, M., Chikaraishi, H., Keira, K.: Development of fire-resistant steel frame building structures, Nippon Steel Technical Report, No. 66, July 1995, s. 29-36.

[2] E119 - Standard test methods for fire tests of building construction and materials, American Society of Testing Materials (ASTM), Philadelphia, PA, USA, 1996.

[3] PN-EN 1993-1-2. Eurokod 3: Projektowanie konstrukcji stalowych - Część 1-2: Reguły ogólne - Obliczanie konstrukcji na warunki pożarowe.

[4] Blicharski M.: Inżynieria materiałowa. Stal. Wydawnictwa Naukowo - Techniczne, Warszawa, 2004.

[5] Mizutani, Y., Yoshii, K., Chijiiwa, R., Ishibashi, K., Watanabe, Y., Yoshida, Y.: 590 MPa class fire-resistant steel for building structural use. Nippon Steel Technical Report, No 90, July 2004, s. 45-52.

[6] Sha, W., Kirby, B. R., Kelly, F. S.: The behaviour of structural steels at elevated temperatures and the design of fire resistant steels. Materials Transactions, Vol. 42, No. 9, 2001, s. 1913-1927.

[7] Maślak M., Skiba R.: Fire resistance increase of structural steel through the modification of its chemical composition. Proceedings of the $7^{\text {th }}$ Scientific - Technical Conference "Material Problems in Civil Engineering" (MatBud 2015), June 22-24, 2015, Cracow, published in: Proceedia Engineering online.

[8] PN-EN 1991-1-2. Eurokod 1: Oddziaływania na konstrukcje - Część 1-2: Oddziaływania ogólne - Oddziaływania na konstrukcje w warunkach pożaru.

[9] Chijiiwa, R., Yoshida, Y., Uemori R., Tamehiro, H., Funato, K., Horii, Y.: Development and practical applications of fire-resistant steels for buildings, Nippon Steel Technical Report, No 58, July 1993, s. 47-55.

[10] http://uratti.web.fc2.com/architecture/senda/tokonamegim4.jpg - [dostęp 04.2015]

[11] http://static.panoramio.com/photos/large/119628624.jpg - [dostęp 04.2015]

[12] http://www.michaeljohngrist.com/wp-content/uploads/2009/01/bigsofitel600x412.jpg - [dostęp 04.2015] 
[13] http://archn.web.fc2.com/t021110/t-sofitel03.jpg - dostep 04.2015.

[14] https://www.google.pl/maps/@35.6103596,140.1144625,3a,75y,54.8h,113.54t/ data $=$ !3m7!1e1!3m5!1siMoZz7ZFu7QuZg9Pq1 yx3w!2e0!5s20141201T000000!7i1 3312 ! $8 \mathrm{i} 6656$ - [dostęp 04.2015]

[15] http://www.yokohamajapan.com/wp-content/uploads/2011/03/Sogo-Yokohama.jpg - [dostęp 04.2015]

[16] https://upload.wikimedia.org/wikipedia/commons/f/fe/SOGO_Yokohama_001. JPG - [dostęp 04.2015]

[17] http://donki.com/en/store/shop_detail.php?shop_id=172 - [dostęp 04.2015]

\title{
SELECTED REALISATIONS OF THE BUILDINGS WITH A LOAD- BEARING STRUCTURE MADE USING THE FIRE RESISTANT STRUCTURAL STEELS
}

\begin{abstract}
S u m m a r y
The examples of the application of the fire resistant structural steels to construct the loadbearing structure in the buildings of the various type, both former and those still being in use, are presented and discussed in detail. It is essential that the steels of this type, due to their characteristics, need not to be specially protected against the potential fully developed fire exposure. Therefore, they seem to be an interesting alternative to the conventional structural steels which require the use of the additional and costly fire insulation. The practical use of the presented fire resistant steels is limited so far to the territory of Japan. This results from the specificity of the building law being applicable in that country. However, some steps in the similar direction have been taken recently also in the countries belonging to the European Union. The main areas of the application of the fire resistant steels are as follows: the tall buildings, including the external load-bearing part of their elevations, the sports facilities, the open multi-story car parks as well as the concert and the other performance halls, especially those with the atria.
\end{abstract}

Keywords: fire-resistant steels, fire, temperature, fire resistance, weldability, strength.

Przestano do redakcji:30.05.2015

Przyjęto do druku:10.01.2016

DOI: $10.7862 / \mathrm{rb} .2015 .196$ 